Global Journal of Arts, Humanities and Social Sciences

Vol.10, No.1, pp.1-20, 2022

Print ISSN: 2052-6350(Print)

Online ISSN: 2052-6369(Online)

\title{
FISCAL FEDERALISM AND RESOURCE CONTROL IN NIGERIA: DECONSTRUCTING A CONUNDRUM
}

\author{
Ejitu Nnechi Ota
}

Department of History and International Relations, Abia State University, Uturu.

\section{Charles O. Okoko}

Department of History and International Studies, Evangel University, Akaeze, Ebonyi State.

\section{Ikechukwu C. Ahamefule}

Department of History and International Studies, Akwa Ibom State University, Ikot Akpaden.

\begin{abstract}
Following the end of the Nigeria-Biafra war in 1970, crude oil exports became Nigeria's major foreign exchange earner, and national politics became a struggle over who controls the country's oil sources and revenues. For nearly thirty years, the military, dominated as it were, by Northern Nigerian officers, kept on tinkering with revenue allocation formulae to the advantage of the North and to the chagrin and dismay of the oil-bearing South. While the latter continued to agitate for a review of the existing lopsided federal structure through restructuring and devolution of powers to enable them control the resources within their communities, the North persisted in its opposition to any change in the status quo. The result has been a lack of trust and acrimony in North-South relations. The paper adopted the qualitative research approach which basically involved content analysis. Among its findings was that the soured relations between the North and the South has impeded national integration, nation-building, and national development. It concluded that there is a compelling need to address the various issues associated with fiscal federalism, revenue allocation, and resource control through a restructuring of the Nigerian polity and economy.This will discourage the endemic and destructive struggle for the federal government between the political elite from both the North and South.
\end{abstract}

KEYWORDS: derivative principle, devolution, fiscal federalism, prebendalism, resource control, restructuring.

\section{INTRODUCTION}

Among the most volatile issues in the Nigerian federation are those of fiscal federation and resource control. Embedded in these is the use of the derivative principle in the allocation of the country's revenues. The principle of derivation in revenue allocation has indeed, been a very

@ECRTD-UK: https://www.eajournals.org/

https://doi.org/10.37745/gjahss.2013 
explosive one, such that it has continued to threaten the stability of Nigeria. In the words of Okechukwu Okeke:

Revenue is allocated routinely among the various sections of the country (among the regions/ states) when a proportion of the revenue collected by the federal government is transferred to the lower levels of government (the state/regional governments, and since 1976, the local government). ${ }^{1}$

Both Douglas Rimmer ${ }^{2}$ and Egite Oyovbaire ${ }^{3}$ agree that derivation, in the context of revenue allocation in Nigeria, is anchored on the belief that the federating units of Nigeria should be given a share of the total national revenue based on the amount realized from the taxes generated from and within their borders. Put differently, the idea is that the principle of derivation in the allocation of revenue between the federal and state governments in Nigeria should be based on how much each states contributes to the national pool/treasury.

The politicization of resources control and revenue allocation was often polarized the country along regional lines. For instance, since more than eighty percent of the country's external earnings is generated by oil exports leaders and indigenes of the oil-bearing communities indeed and states in the south have been agitating for a revenue sharing formula that will give them about half of what the federal government takes from their land. On the other hand, politicians and representatives of non-oil producing states, (especially the North), have consistently opposed any such sharing formula because according to them, whatever resources that are found in any part of Nigeria belongs to all Nigerians ${ }^{4}$.

\section{Fiscal Federalism and the Derivative Principle}

The concept of fiscal federalism can best be understood against a background of a definition of the word "federalism". According to Ian Mclean and Allistair McMillian:

The term federalism...is most commonly employed to denote an organizational principle of a political system, emphasizing both vertical power-sharing across different levels of governance... and at the same time, the integration of different territorial and socio-economic units, cultural and ethnic groups in one single polity. Federal political systems are hence often viewed as combining 'unity with diversity...5

Two things are obvious from this definition, and they are in consonant with the definition, and they are in consonant with the definitions of federalism by both Kenneth C. Wheare ${ }^{6}$ and A.V. 
Dicey, ${ }^{7}$ two experts in the study of federalism. In the first place, the concept of federalism mans that in a federal system, there is a division of legislative powers among the levels of government. This is of course, provided for in the constitution. Secondly, the concept of federalism implies that a federal system of government is adopted as a deliberate political strategy designed to contain and mitigate the impact of centrifugal forces and fissiparous tendencies in a plural society or polity.

Contextually, the federal system of government in Nigeria was introduced by the British colonial regime in order to achieve its economic objective of exploiting the peoples and resources of Nigeria. For them, it was the preferred option to tackling the ethnic plurality and other differences in the country. Thus, both the Macpherson, the Lyttleton constitutions of 1951 and 1954 respectively introduced and amplified the federal system in Nigeria as a means of stemming the tide of ethnic and regional animosities and antagonism in the country. Subsequent constitutions since 1957 have retained federalism as the system of government in the country. Since 1966, however, federalism as applied by a succession of governments in Nigeria, (military and civilian) has abandoned the basic principles and ingredients of federalism (such as decentralization of power and financial autonomy) in favour of what can be justifiably referred to as "unitary federalism". This is a situation whereby the Federal government in Nigeria controls the bulk of the national financial resources and gives out statutory monthly allocations to state and local governments on the following basis. Federal government- 56\% states-24\%; and local governements-20\%.

Having attempted a definition of federalism and having equally tried to briefly examine its origin in Nigeria, it is now imperative to define fiscal federalism and situate it in the context of Nigerian federalism. As a concept "fiscal federalism" owes its origin to Richard Abel Musgrave, a United States economist of German heritage, in his book "The Theory of Public Finance: A study in Public Economy”, published in 1959. Musgrave's main thesis is that any federal government is capable of managing the financial resources available to it and efficiently share part with states who will in turn distribute it to local governments. That way, many of the problems faced by state and local governments would be solved by the federal government's extension of financial assistance to them. In other words, fiscal federalism is"... that aspect of federalism that concerns the financial and attendant functions and responsibilities of component units within a federal structure" 8 .

All too often, many in Nigeria assume that fiscal federalism only has to do with financial relations between the federal state and local governments; that is, how the federal government share sits revenue with other two tiers of government. But that is wrong. As a matter of fact, it has to do more with how the revenues are generated, allocated and redistributed in a federal system, such as Nigeria. Thus, how taxing, spending and regulatory functions are allocated among the tiers of governments as well as inter-governmental transfers structures, all constitute the principles of fiscal federalism. In essence, it is about how revenue is generated internally and shared among the three levels of government in order to achieve national development. 
From the regional system of government which Nigeria operated from 1949 to 1967, to the federal system based on states which country has operated since 1967, the issue of revenue allocation based on the derivative principle, has remained a hard nut to crack. Due mainly to the country's complex matrix of cultural pluralism, including, as it were, ethnicity formulae in the country have continued to generate ill-feelings ${ }^{9}$. This is especially the case since the discovery of oil in commercial quantities in the Niger delta, and its status as the country's largest revenue earner.

Historically, the federal government has always controlled more financial resources vis-à-vis the component units of federation-firstly, regions and provinces, later states and local government areas. For instance, as far back as 1946, the Phillipson Commission had been set up by the colonial government on the issue of revenue allocation. It was mandated to formulate the administrative and financial system which the government of the day was to adopt under the Richards constitution $^{10}$. That Commission recommended that $50 \%$ of the revenue should be retained by the region of origin, (including the region of origin), while the central government was to be left with $15 \%{ }^{11}$. According to Okwudiba Nnoli, licenses for and taxes on hunting, liquor, motor vehicles, as well as those from rents on mining rights and leases, court fees, water supply projects, direct and income taxes, and reimbursements and sundry other sources, were the major revenue earners for the region. On the other hand, the central government's sources of fund were mostly from customs duties, interest, posts and telegraphs, railways, direct tax, fees, excise duties, export duties, company tax, corporation tax, mining royalties, and the profits of public corporations ${ }^{12}$.

Eventually, the Hicks-Phillipson Commission (1951), the Chick Commission (1953), the Raisman (1964) were set up to find solutions to the intractable problems associated with revenue allocation in colonial and early post-colonial Nigeria. As earlier stated, the Hick-Phillipson Commission retained the derivative formula of $50 \%$ for area of origin, $35 \%$ for the regions, and $15 \%$ for the central government which its predecessor, the Phillipson Commission, had recommended 50\% for derivation, $30 \%$ for the regions and $20 \%$ for the central government, while the Binn's Commission recommended $50 \%$ for the region of origin and $15 \%$ for the central government. Through the military coup d'etat of January '1966 frustrated the full implementation of the Binn's Commission revenue allocation formula only a year, it, nonetheless, remained in force as a workable formula for the three regions and later twelve states until $1970^{13 .}$

Thus, just like the situation in the period before the promulgation of the Richards constitution when the central government controlled most of the sources of revenue and often provided financial assistance to the provinces, in the period after 1946, the federal government still controlled enormous financial resources. That was why the Hicks-Phillipson Commission of 1951 recommended revenue allocation to be based on the principle of derivation and even progress-50\% for the area of origin, $35 \%$ for the Region, and $15 \%$ for the central government. This was the formula suggested earlier by the Phillipson Commission the derivation to be based on principles 
of $50 \%$ for the area of origin, $35 \%$ for the Region, and $15 \%$ for the central government. However, the federal government decided to first-study the practical difficulties of implementing the report before accepting it. It is instructive to note that the Richards constitution had divided Nigeria into three regions-East, North and West. The struggle for the excess fund from the central government became intense because for one thing, only a fraction of the revenue of the central government was needed to run its institutions and agencies; and for another, there had emerged in1951, ethnicallybased political parties (the Action Group and the Northern Peoples congress), following the promulgation of the Macpherson constitution. Therefore, the politicization of ethnicity combined with the regionalization of politics to put enormous pressure on the central government to devise modalities for sharing national wealth.

However, beginning from the Phillipson Commission of 1946, there have always been difficulties arising from the implementation of all the commissions ever set up to recommend revenue sharing formulae in Nigeria and the financial relationship between the central government and the component units of the federation. For instance, there were claims and counter-claims of unfair revenue allocation between the Northern Regions, on the other. While the former argued that money meant for it had unfairly assigned to the latter, the Eastern and Western Regions cried foul over what they claimed was the unfairly large allocation given to the Northern Region. In fact, the dispute over the Phillipson Commission's recommendation for allocation to be based on the principles of derivation and even progress nearly truncated the Ibadan Constitutional Conference of 1950 .

Prior to the abandonment of the regional system consequent upon the creation of states in 1967, derivation was the main basis on which revenue was allocated. Though population and basic needs were also part of the criteria, these were considered secondary in the allocation of revenue among the then existing four regions. But the creation of states exercise which, as earlier stated, began in 1967, led to the inclusion of such other criteria as population equality of states, land mass, educational levels, the number of local government areas, and revenue generation efforts by the states of the federation. At this time, the exports of crude oil had become Nigeria's major revenue earner.

According to Okeke, the weight given to the derivation principle and the later population and need in the allocation of revenue to the regions was because of the need to reduce the gap in their relative fiscal capability and the gap in their relative fiscal capability and development efforts ${ }^{14}$. However, revenue earnings from crude oil exports in the early 1976's tended to widen the gaps in development and the provision of social and economic amenities between oil producing states and their non-oil producing counterparts. In other words, statutory allocations to states like the former Rivers, Mid-West and East Central states (now Bayelsa, Rivers, Edo, Delta, Abia Anambra, Imo, Ebonyi and Enugu states) from the federal government, was $50 \%$ because these states have oil- 
bearing communities. Thus, the military-led federal government decided in late 1974, to remove the weight of derivation in its revenue allocation formula from $50 \%$ to $20 \%$. This took effect from the 1975-1976 financial year ${ }^{15}$.

The Implication of the new revenue sharing formula (which now had population, land mass, educational backwardness, number of local government areas, and equality of states), was that the oil producing states share of the national revenue was drastically reduced. Of course, they protested as the federal government continued to de-emphasize derivation in subsequent revenue sharing formulas. From 50\% to $20 \%$ in the 1975-1976 financial year, the percentage of revenue allocation based on derivation, progressively plummeted to $2 \%$ in 1982 to $10 \%$ in 1990 . Ironically, population as a criterion for revenue allocation was given a weight of $40 \%$; equality of states $40 \%$; social development factor 15\%; and internal revenue efforts, 5\% ${ }^{16}$. However, subsequent adjustments over the years have made some alterations. For instance, the weight assigned to population has been reduced to $30 \%$ while internal revenue effort and social development factors as well as land mass and terrain were given $10 \%$ each as at 2004.

But population was still accorded $40 \%$ within the same period (2004). Today, derivation is $13 \%$ and is now constitutional, based on the 1999 constitution of the Federal Republic of Nigeria (as amended). Specifically, sector 162 (2) provides that, “... the principle of derivation shall be constantly reflected in any approval formula as being not less than thirteen percent of the revenue accruing to the Federation Account directly from any natural resources"17.

\section{Revenue Allocation and Resource Control.}

It has been rightly pointed out that the problems of revenue allocation in Nigeria, despite the various recommendations and their implementation right from the colonial times to the present has remained a sore spot $\mathrm{n}$ Nigeria's search for real nationhood ${ }^{18}$. "It has remained an emotional, sensitive, and highly politicized issue" writes Nnoli ${ }^{19}$. This has been especially so since Nigeria became country in 1960. Beginning from the 1968 I.O. Dina- led Interim Revenue Allocation Review Committee (IRARC) set up by the then military government, to the Aboyade Technical Committee on Revenue Allocation of 1977, and the Okigbo Revenue Allocation Commission of 1979, to the National Revenue Allocation and Fiscal Commission of 1988 led by T.Y. Danjuma a retired Army General, extant Revenue Mobilization Allocation and Fiscal Commission (RMAFC) set up in 1999 by Olusegun Obasanjo (as democratically-elected President), the issue of revenue allocation has continued to generate disaffection and ill-feelings across the length and breadth of Nigeria, especially between those states whose communities are oil-bearing and others.

Revenue allocation has been defined as, “... simply a process by which monies generated internally are shared among the different units of a country" ${ }^{\prime 2}$. In Nigeria, the massive increase in 
crude oil exports since the 1970s and the attempt explosion of revenue accruing to the federal government over the years have generated controversies over how it should be shared between the different levels of government. In the main, this is because despite its control of such exclusive revenue-generating areas as the Value Added Tax (VAT) (introduced in 1994), the Autonomous Foreign Exchange Market (AFEM) and the now defunct Petroleum Trust Fund (PTF), the federal government under Sani Abacha's military dictatorship 1993-1998 cared less about the extant revenue allocation formula. For instance, ordinarily, the collection of VAT (which is nothing else but sales tax), should fall within the purview of states. In other words, such taxes should accrue to the states who will in turn, pay a certain percentage to the coffers of the federal government. But the federal government initially appropriated $80 \%$ and left $20 \%$ for the states, through this was later reversed to $33 \%$ for the local government, $35 \%$ for states, and $30 \%$ for local governments, following agitations by states for a review of the sharing formula ${ }^{21}$.

As a matter of fact, the federal government's overarching control revenue earnings and its unwillingness over the years to adopt a revenue sharing formula that will favour the states (especially those of the Niger Delta whose communities produce the oil) is a constant reminder of the fragility of the Nigerian state. There have been agitations for resource control by states in the Niger Delta. Youth there have on a number of occasions expressed their grievances by resorting to the destruction of the facilities and kidnapping the staff of international oil companies (IOCs). Military in the Niger Delta have combined to impact negatively on Nigeria's economic lifelinecrude oil production and exports. Although the federal government has often adopted some palliative policies in addressing the grievances of oil-bearing communities and states, such measures and strategies have not been successful in obliterating the spectre of domination exploitation and marginalization on the part of the indigenes and leaders of states in the Niger Delta.

They have continued, along with other states in the southern part of Nigeria, to demand for a review of the revenue-sharing formula by putting more weight on the principle of derivation. They have also been agitating to be allowed to control and exploit the resources in their states and only pay taxes to the federal government as was the case during the colonial era. At that time, the regions in the country enjoyed financial independence, especially from 1954 to 1966 . While the Northern region got its revenue from sale of groundnuts, cotton and columbite, among others, the West benefited from revenues accruing from the sales of cocoa and rubber, among others, while the East depended largely on palm produce. In 1954, the Louis Chick Commission on revenue allocation unequivocally emphasized the need to adopt and apply the principle of derivation in revenue allocation. It also recommended the discretionary extension of financial assistance to the regions in times of financial difficulties. 
The application of the derivative principle at that time favoured the West and the North vis-à-vis the East whose main source of revenue had declined due to competition and the availability of other types of vegetable oil in the international market. However, the tide changed later in 1957 when there were falls in the revenue earnings from the exports of cocoa for the West and North respectively. They were now faced with the realities that had earlier confronted the East which had benefited the least from the derivative principle. The North was particularly hard hit by the new economic realities because, in relation to its size and need, it no longer considered the derivative principle a realistic basis for revenue allocation. The region, therefore, became apprehensive, and vehemently opposed the continued application of the derivative principle. In the end, the Raisman Commission on revenue allocation which was approved by the Constitutional Conference of 1957, de-emphasized the principle of derivation in revenue allocation. According to Nnoli, the Raisman Commission now took the following factors into consideration in revenue allocation:

i. Population

ii. The basic responsibilities of each regional government

iii. The need for continuity in regional public services, and,

iv. The need for a balanced development of the country. ${ }^{22}$

The Commission also recommended that there should be a "distributable pool" or excess revenue accruing to the federal government which should be allocated to the regions in the following order:
i. $\quad 40 \%$ to the North
ii. $\quad 24 \%$ to the West
iii. $\quad 31 \%$ to the East, and
iv. $\quad 5 \%$ to the Southern Camerouns ${ }^{23}$.

Furthermore, it recommended that mining rents and royalties should be allocated as follows:

i. $\quad 50 \%$ to the region of origin

ii. $\quad 20 \%$ to the federal government,

iii. $\quad 30 \%$ to the "distributive pool". ${ }^{24}$

There was an agreement among the regional governments on the need for the federal government to appoint, from time to time, a commission to revenue allocation in the country. But it was only the Binn's Commission that was ever appointed before the intervention of the military in national politics. When it was appointed in 1965, the Binn's Commission as earlier pointed out, recommended $50 \%$ for the region of origin and $15 \%$ for the central government. In addition, it acceded to the demands of the regional governments for a substantial increase in the distributable pool as well as the payment of annual block grants to the regions on the following basis. 

i. $\quad 53.3 \%$ to the North
ii. $\quad 21.3 \%$ to the East
iii. $\quad 16 \%$ to the West, and
iv. $\quad 9.3 \%$ to the newly Mid-Western region. ${ }^{25}$

The idea behind this was to enable the regions to utilize their own recurrent budgets in financing development projects and programmes in their various regions. In other words, the regions were now placed in a comparable financial position which would enable each of them formulate financial policies based on the resources available to it which would then argument with the annual grants from the central government.

\section{The politicization or revenue allocation and the agitation for resources control}

Although the centralization of fiscal powers in Nigeria date back to the colonial era, party politic and military rule exacerbated the situation. Since 1960, for instance, the North has continued to be the major beneficiary in terms of revenue allocation. Because it has controlled the federal government for the most part since independence, the leadership of Northern Nigeria has consistently ensured that it frustrates any and every effort which it considers as a threat to its political and economic interests in the country. Sometimes, it has set impossible conditions on the exploitation of mineral resources in the North, while using the so-called 'federal might' to push through policies that would facilitate the exploitation such resources in the south, especially in the Niger delta oil-bearing communities. For instance, in the First republic (1960-1965), the North rejected the federal government's plan to exploit the iron ore deposits in that region unless the proposed iron and steel industry would be sited in the North. Also, following falling commodity prices and the concomitant depletion of the finances of the regional governments, these regions began to depend more and more on federal resources to finance their capital development projects.

In the period of the First National Development Plan (1962-1966), Northern Nigeria had problems of rising recurrent expenditure as well as fluctuations in its revenue-generating sources. By implication, it also experienced deficits in its recurrent budgets and depleted reserves. Because it controlled the federal government, the North, according to Nnoli, “... expected 56 per cent of its total "internal" financial resources and 37 per cent of its overall total to come from the federal government $^{26 "}$. Thus, in the said First National Development Plan, the federal government's resources which were transferred to the North amounted to the equivalent (in 1978) of N58.2million, compared with N39.8 to the West, and N24 million to the East. ${ }^{27}$

This dependence on the federal government by its constituents parts was made worse following the creation of states, first in 1967 (12 states), followed by 1976 (21 states), 1991 (30 states), and 1996 (36 states). Many of these states are not viable economically because of diminished

@ECRTD-UK: https://www.eajournals.org/ https://doi.org/10.37745/gjahss.2013 
internally-generated revenue bases. As earlier mentioned, the federal government also took over some of the sources that should have increased the revenue base of the states, such as the VAT and even personal income tax. These are in addition to petroleum profit tax, mining rents and royalties, company incomes tax, customs and excise duties, et cetera. Various states over creation exercise have favoured the North over the south. The same is true with the creation of local government areas by the federal government over the years. Those states and local government areas are not viable because vis-à-vis the expenditures posed by their statutory responsibilities, their internally generated revenues are always very $\operatorname{low}^{28}$. In the words of G.D. Olowononi, “Internally generated revenues constituted only 12.84 per cent of all the states' total current revenue in 1991, 17.76 per cent in 1993 and 24.19 per cent in 1995". ${ }^{29}$

Since the colonial era, the various central governments have always introduced or implemented legal and political constraints to enable them control the country's natural resources. These have served to consolidate, in recent years, the federal government's accumulation of both political power and the national wealth. For instance, Section 69 and item 25 of the 1960 constitution (the Independence Constitution) vested the exclusive on the parliament power to legislate on mines, minerals, oil mining, geological surveys, and natural gas, among others. This position was retained by the 1963 Republican Constitutions provided for $50 \%$ of derivation fund to be paid to any mineral-producing region. In 1969, the petroleum Decree of that year was issued essentially to address the controversy over ownership and control of all petroleum resources and revenues accruing thereform. In 1990, that decree was enacted as the Petroleum Act, Cap 350, Laws of the Federation. Its recital provides thus:

An Act to provide for the exploration of petroleum from the territorial waters and the continental shelf of Nigeria and to vest the ownership of and all onshore and offshore revenue from petroleum resources derivable therefrom in the federal government and/or all other matter incidented thereto. $^{30}$

The recital (or commencement) of the Act says:

1. The entire ownership and control of all petroleum in, under or upon any lands to which this section applies shall be vested in the state [that is, the Federal Government].

2. This section applies to all land (including land covered by water) which

a. Is in Nigeria; or

b. Is under the territorial waters of Nigeria; or

c. Forms part of the continental shelf. ${ }^{31}$

Based on this Act, the Federal government had the executive right of control in respect of petroleum resources in any part of the country. Of course, it is only in the Niger Delta that crude 
oil is being exploited. The Law also vested in the Federal government the exclusive ownership of all revenues accruing from both the exploitation and sale of petroleum resources, subject to Section 16 (2) (Economic Objectives) of the Nigerian Constitution, 1999, (As Amended). This authority of the federal government in respect of ownership of petroleum resources and the derivable revenue has been reinforced by the Land Use Act, Laws of the Federation of Nigeria, 1990. Part I, Generally, of the Act provides that:

1. Subject to the provision of this Act, all land comprised in the Federation are hereby vested in the Governor of that state and such land shall be held in trust and administered for the use and common benefit of all Nigerians in accordance with the provisions of this Act. ${ }^{32}$

The implication is that the government can seize, without any form of compensation, any land whose owner does not have Certificate of Occupancy. The Act effectively abrogates the right of individuals to land ownership, including the natural resources inside such lands.

Both the Land Use Act and the Constitution (of course, the Land Use Act is part of the 1999 Constitution) have combined to make it impossible for individuals and communities to own exploit and sale natural resources found in their lands. The constitution, in particular, provides that all mineral resources in Nigeria are under the exclusive jurisdiction of the federal government. Section 44 (3) of the 1999 constitution provides that:

Notwithstanding the foregoing provisions of this section, the entire property in and control of all minerals, mineral oils and natural gas, under or upon any land in Nigeria or in, under or upon the territorial waters and the Exclusive Economic Zone of Nigeria shall vest in the Government of the Federation and shall be managed in such manner as may be prescribed by the national Assembly ${ }^{33}$.

Put in other words, the 1999 constitution has legally permitted the federal government to literally confiscate the revenues that should ordinarily belong to the component units. As a result, there have been arguments in support of and against the usurpation of what some consider the powers of the states by the federal government, especially in the area of resource ownership and control.

\section{The Resource Control conundrum}

David Dafinone has defined resource control as:

... a basic economic theory grounded in the fact that land, labour, capital and entrepreneurship are factors of production... just a s the price of labour is wages, capital has interest, entrepreneurship is driven by profit while rent and royalties are rewards for land ownership. Rent is a return for the use of the original land and indestructible properties of the soil, whoever owns a land 
expects some form of compensation from those hiring this very important factor of production. The clamour for resource control is a clamour for adequate compensation a cry for redistribution of the revenue allocation formula... ${ }^{34}$

This means that resource control basically has to do with the control and management of natural resources as well as revenue sources by the state or local governments within whose land such natural resources are extracted and revenue generated. In other words, it means the demoretization of control over resources in line with the principles of federalism.

In Nigeria, the agitation for resource control is anchored on the fact that over the years, the derivative principle in revenue allocation has lost its weight to other considerations which have favoured non-oil producing states, to quote Okeke:

The agitation for resource control arose from the frustration of the oilproducing states [of the Niger]... over the policy of successive federal governments to de-emphasize derivation. The oil-producing states believe[d] that they were [are] being denied what was [is] due to them, and that this was possible because they were politically weak in relation to the non-oil producing states. Another reason for the agitation was [is] that opinion leaders in the oil-producing states were [are] convinced that the federal government, headed from 1979 to 1999 by Northerners, had been cheating the oil-producing states in the expenditure of its own share of oil revenue. They were [are] of the view that the federal government heavily favoured the northerners in the location of projects and award of contracts and licenses. This opinion we might add, was [is] valid, and was [is] shared by opinion leaders in other southern states. ${ }^{35}$

There is, of course, no doubting the fact that the increasing relevance of oil exports as Nigeria's major source of revenue earner since the 1970s and the domination of the federal government by Northerners (whether as heads of military juntas or as elected Presidents) Have resulted in prebendal and ethnic politics. The Northern Nigerianoligarchy has consistently used its domination of the federal tier of government to not only ensure that the federal government controls the bulk of national revenue, but to also introduce other principles of revenue allocation which have favoured the North more than other parts of the country (especially the Niger Delta) by reducing the weight assigned to the principle of derivation ${ }^{36}$. For instance, the North has more states and local government areas than the West and the East combined. It also controls the federal legislature because representation in the National Assembly is based on the number of states and local government areas. Indeed, as has been rightly observed: 
The number of local government areas is one of the most important criteria used in alllocating the local governments' share of the Federation Account among the local government areas (LGAs) in each state. thusm a state that has more LGAs get a higher share than a state that has less. The distribution of LGAs among states in 1991 and 1996 [when new on the basis of political considerations rather than objective criteria. Thus, some states got unduly higher numbers of $\mathrm{LgAs}$ than others. For instance, Kano, the second most populous state according to the 1991 census results, has 44 LGAs, whereas Lagos, the most populous state , has just $20 .{ }^{37}$

It is for these reasons that the states of the core Niger Delta (Akwa Ibom, Bayelsa, Edo and Rivers) and those of the peripheral Niger Delta (Abia, Imo and Ondo) feel short-changed by the federal government.

Out of the over thirteen governments (military and civilian) that have ruled Nigeria since independence in 1960, And in spite of the N96.212 trilion that has been generated from oil exports since 1958 (when oil in commercial quantities was discovered in Oloibiri), thE oil-producing areas have received only N12.3 trillion as derivation. Also, whereas the derivative principle was $50 \%$ in the First Republic (when the total earning from oil exports has N19.4million and N45.7 million was paid as derivation) and the J.T.U. Aguiyi-Ironsi military government (January -June, 1966) paid N45.8 million as derivation, nothing was paid to the oil-producing states for fourteen years by the military regimes of both Yakubu Gowon and Murtala Mohammed/Olusegun Obasanjo ${ }^{38}$.

The agitation for resource control was initiated by the Movement for the Survival of the Ogoni People (MOSOP) who demanded, in 1009-1993 for the right to own control, and manage the oil resources in their lands. The MOSOP, in its Ogoni Bill of Rights, also accepted to contribute to the till of the federal government. As earlier stated, opinion leaders from the other oil-producing communities and states in the South later keyed into the position of MOSOP ad advocated for resource control. They believe that the northern-led federal governments have, over the years, used their control of that tier of government to marginalize the states in the south while also favouring states in the north. 
How derivation was paid

\begin{tabular}{|l|l|l|}
\hline Regime & Revenue [N] & Derivation [N] \\
\hline Balewa/Azikiwe & $91.4 \mathrm{~m}$ & $45.7 \mathrm{~m}$ \\
\hline Ironsi & $23 \mathrm{~m}$ & $11.5 \mathrm{~m}$ \\
\hline Gowon & $12.73 \mathrm{~b}$ & NIL \\
\hline Mohammed/Obj & $25 \mathrm{~b}$ & NIL \\
\hline Shagari & $30 \mathrm{~b}$ & $225.7 \mathrm{~m}$ \\
\hline Buhari & $12.5 \mathrm{~b}$ & $37.5 \mathrm{~m}$ \\
\hline Babangida & $400.2 \mathrm{~b}$ & $12.01 \mathrm{~b}$ \\
\hline Shonekan/Abacha & 1.44 trn & 3.1 trn \\
\hline Abubakar & $394.77 b$ & $11.84 \mathrm{~b}$ \\
\hline Obasanjo & & 3.1 trn \\
\hline Yar'Adua & $23.83 t r n$ & 1.71 trn \\
\hline Jonathan & 13.12 trn & $\mathbf{6 . 6 3 t r n}$ \\
\hline Buhari & $\mathbf{5 1 t r n}$ & \\
\hline
\end{tabular}

Source: Sunday Vanguard Newspaper, 21-08-10 
Crude oil earnings and derivation since 1958

\begin{tabular}{|c|c|c|}
\hline YEAR & REVENUE (N) & DERIVATION (N) \\
\hline 1958 & 0.2 million & 0.1 million \\
\hline 1959 & 3.4 million & 1.7 million \\
\hline 1960 & 2.4 million & 1.2 million \\
\hline 1961 & 17 million & 8.5 million \\
\hline 1962 & 17 million & 8.5 million \\
\hline 1963 & 10 million & 5.0 million \\
\hline 1964 & 16 milion & 8.0 million \\
\hline 1965 & 29 million & 14.5 million \\
\hline 1966 & 45 million & 22.5 million \\
\hline 1967 & 30 million & 15.0 million \\
\hline 1968 & 15 million & ---- \\
\hline 1969 & 75.4 million & ---------------- \\
\hline 1970 & 167 million & -- \\
\hline 1971 & 510 million & ---- \\
\hline 1972 & 764 million & --- \\
\hline 1973 & 1.016 million & -- \\
\hline 1974 & 3.724 billion & --- \\
\hline 1975 & 4.272 billion & --- \\
\hline 1976 & 5.368 billion & --------- \\
\hline 1977 & 6.081 billion & -- \\
\hline 1978 & 4.556 billion & ------ \\
\hline 1979 & 8.881 billion & ---------- \\
\hline 1980 & 12.354 billion & --------- \\
\hline
\end{tabular}

@ECRTD-UK: https://www.eajournals.org/ https://doi.org/10.37745/gjahss.2013 
Global Journal of Arts, Humanities and Social Sciences

Vol.10, No.1, pp.1-20, 2022

Print ISSN: 2052-6350(Print)

Online ISSN: 2052-6369(Online)

\begin{tabular}{|l|l|l|}
\hline 1981 & 8.564 billion & ------------- \\
1982 & 7.815 billion & 117.9 million \\
1983 & 7.253 billion & 108.795 million \\
1984 & 8.264 billion & 123.96 million \\
1985 & 10.915 billion & 163.725 million \\
1986 & 8.107 billion & 121.6 million \\
1987 & 19.027 billion & 285.05 million \\
1988 & 20.934 billion & 314.01 million \\
1989 & 39.131 billion & 586.96 million \\
1990 & 55.216 billion & 828.24 million \\
1991 & 60.314 billion & 904.71 million \\
1992 & 115.392 billion & 3.462 billion \\
1993 & 106.192 billion & 3.204 billion \\
1994 & 160.192 billion & 4.830 billion \\
1995 & 324.548 billion & 9.736 billion \\
1996 & 369.190 billion & 11.076 billion \\
1997 & 416.811 billion & 12.504 billion \\
1998 & 289.532 billion & 8.686 billion \\
1999 & 500.00 billion & 32.5 billion \\
2000 & 1.34 trillion & 174.23 billion \\
2001 & 1.708 trillion & 221.91 billion \\
2002 & 2.074 trillion & 160.017 billion \\
2003 & 3.355 trillion & 269.659 billion \\
2004 & 4.7624 trillion & 619.112 billion \\
2005 & & \\
\hline
\end{tabular}

@ECRTD-UK: https://www.eajournals.org/

https://doi.org/10.37745/gjahss.2013 


\begin{tabular}{|l|l|l|}
\hline 2006 & 6.109 trillion & 794.17 billion \\
2007 & 6.70 trillion & 871 billion \\
2008 & 3.96 trillion & 514.8 billion \\
2009 & 2.225 trillion & 289.307 billion \\
2010 & 9.15 trillion & 1.190 trillion \\
2011 & 5.561 trillion & 722.91 billion \\
2012 & 12.5 trillion & 1.625 trillion \\
2013 & 12.6 trillion & 1.638 trillion \\
2014 & 11.891 trillion & 1.546 trillion \\
2015 & 6.945 trillion & 903.85 billion \\
2016 (June) & 1.499 trillion & 194.87 billion \\
TOTAL & 96.212 trillion & 12.258 trillion \\
\hline
\end{tabular}

Source: Petroleum Inspectorate, NNPC ; CBN Annual Report and Statement of Account 2008; National Bureau of Statistics, NBS; NEITI; and Sunday Vanguard's research.

\section{CONCLUSION}

Agitations for the adoption of fiscal federalism and the attendant agitations for resource control have found expression in the demand of oil-producing states in the Niger Delta (states in the south of Nigeria generally) for fundamental constitutional changes. Such changes, it is argued, will enable them derive more benefits from the mineral resources that are extracted from their northern counterparts, secretly supported by the Abacha-led and northern-dominated military regime, vehemently opposed it, the position of Northerners has sometimes been ridiculous, such as that they are also entitled to share in the oil resources the Niger Delta because the vegetation of that region, including the faeces, dead bodies, animal remains and fertile lands of the northern peoples, were washed down and stored in Niger Delta over years back ${ }^{39}$. Meanwhile, the extraction of solid minerals in the North, for example, gold mining in Zamfara State is not controlled by the federal government. Rather it is the state government that controls the gold deposits. This is in spite of the fact that the Nigerian Minerals and Mining Act of 2007 provides that, like the oil in the Niger Delta, solid mineral deposits shall be vested in the federal government. ${ }^{40}$ 
More than anything else, it is the domination of the federal government by the North since independence and its corresponding capturing of Nigeria's national wealth $80 \%$ of which comes from crude oil export sales) that has generated ill feelings between states and politicians in the South against their Northern counterparts. In the mid-1970s, pipelines were laid to transport crude oil from the Niger-Delta and the South-East to the North. The refinery in Kaduna which gets its supplies of crude oil through these pipes is much more modern than the ones in the oil-rich Rivers State. Meanwhile, when it was agreed in the First National Development Plan (1962-1968) to site an iron and steel complex in the then Eastern region, politicians and technocrats from the North objected to it, arguing that the raw materials (iron ore) from their region could not be used to service an industry in the East. ${ }^{41}$

Because emotions have been allowed to mix with reason, national integration and nation-building have continued to elude Nigeria. It has been observed that, “... the federal government (FG) has been guilty of the rapacious accumulation of power and the nation's wealth to the detriment of the federating units..." ${ }^{42}$. But it is not just this that is the main issue: there is also the fact that like the federal government, state, and local governments have not exhibited much financial responsibility in managing the funds available to them.

One way of addressing the various thorny issues associated with fiscal federalism, revenue allocation and resource control, is to make constitutional changes: that is to restructure the current unitary federal system. This will enable states in the country to be more pragmatic financial, management and fully exploit other resources of revenue instead of depending on the federal government for survival. Prebendalism, ethnicity and primordial sentiments which characterize national politics, should be jettisoned. Also, there should be devolution of powers from the federal to state governments to reflect true federalism. The unitary federal system adopted by the Ironsiled military regime in 1966 has for political expediency and has now outlined its usefulness. It should be abandoned. Finally, there should be a reduction in the financial resources available to the federal government. This will make control of the federal government less attractive and less acrimonious. When this is done, an important move would have been made towards addressing the challenges of national integration, nation-building, and national development.

\section{References}

1. Okechukwu Okeke, "the politics of revenue allocation in Nigeria since 1960", In Okechukwu Okeke, et al (eds) Issues in Contemporary Nigerian History. Port Harcourt: Educational Books and Investments Ltd, 1998, 215

2. Douglas Rimmer, “The economy since 1970", In Anthony Kirk-Green and Douglas Rimmer, Nigeria since 1970: A political and Economic Outline (London: Hodder and Stoughton, 1982), 123. 
Global Journal of Arts, Humanities and Social Sciences

Vol.10, No.1, pp.1-20, 2022

Print ISSN: 2052-6350(Print)

Online ISSN: 2052-6369(Online)

3. S.Egite Oyovbaire, "The Politics of Revenue Allocation", In Keith Panter-Brick (ed), Soldiers and Oil: The Political Transformation of Nigeria. (London: Routledge, 1978), 224-249.

4. Obi Emeka Anthony, "Sharing the National Cake: A political Economy of the Resource Control Phenomenon in Nigeria's Fourth Reoublic", In Obi Emeka Anthony and Sunday Obiajulu (eds), Federalism and National Integration in $\mathrm{N}$ igeria. (Onitsha: Abbot Communications, 2004), 103-104.

5. Iain McLean and Allistiar McMilllian (eds) Oxford Concise Dictionary of Politics. Oxford: Oxford University Press, 2003, 194.

6. K.C. Wheare, Federal Government. (New York: Oxford University Press, 1963).

7. A.V. Dicey, Introduction to the study of the Law of the Constitution. (London: The Macmillian Press, 1939).

8. Kayode Oladele, "Fiscal federalism and development in Nigeria: An overview od core issues". Saharareporters.com. Accessed on February 28, 2019.

9. Olutayo C. Adesina, "Revenue allocation commissions and contraduictions in Nigeria's federalism," In Amuwo, et al (eds), Federalism and political restructuring in Nigeria, 232.

10. Gini Mbanefoh, "Public Finance", In M.O. Kayode and Y.B. Usman (eds), Nigeria since Independence. The First Twenty-Five Years, vol.11: The Economy. (Ibadan Heinemann Educational Books. 1989), 191.

11. David Dafinone, "The 13\% derivation fund controversy". Dawodu.com. Accessed on March 1, 2019.

12. Okwudiba Nnoli, Ethnic Politics in Nigeria. Enugu: Fourth Dimension Publishers, 1978, 202.

13. Dafinone, "The $13 \%$ derivation fund controversy.

14. Okeke, "The Controversy over resource control ub Nigeria:, In Okechukwu Okeke, et al (eds), Issues in contemporary Nigerian history, 47.

15. Okeke, "The controversy...", In Okeke, et al (eds), issues in Contemporary Nigerian history, 48.

16. Gini Mbanefo and Festus O. Egwaikhide, "Revenue allocation in Nigeria: Derivation Principle revisted", in Kunle Amuwo et al (eds), Federalism and Political restructuring in Nigeria. Ibadan: Spectrum Books Ltd, 2004, 215.

17. The Constitution of the Federal Republic of Nigeria, 1999 (As Amended).

18. Nnoli, Ethnic Politics In Nigeria, 205

19. Nnoli, Ethnic Politics In Nigeria, 205

20. Joseph Athanasius, "Problems and prospects of Revenue Allocation in Nigeria". Infogudenigeria.com Accessed on February 28, 2019.

21. Adeshina, "Revenue allocation commissions...", In Amuwo, et al (eds), Federalism and Political Restructuring in Nigeria, 242. 
22. Nnoli, Ethnic Politics In Nigeria, 205

23. Nnoli, Ethnic Politics In Nigeria, 205

24. Nnoli, Ethnic Politics In Nigeria, 205

25. Nnoli, Ethnic Politics In Nigeria, 205

26. Nnoli, Ethnic Politics In Nigeria, 205

27. Edwin Dean, Plan Implementation In Nigeria (Ibadan: University of Ibadan Press, 1972), 247.

28. G.D. Olowononi, "Revenue allocation and economics of federalism”, in Amuwo et al (eds), Federalism and Political Restructuring in Nigeria, 251.

29. , "Revenue allocation...", in Amuwo et al (eds), Federalism and Political Restructuring in Nigeria, 252.

30. Nigerian PETROLEUM ACT CAP 35OLFN 1990 ACT and CAP 10, LFN 2004. Accessed on February 4, 2019, nigerianlawguru.com

31. Nigerianlawguru.com, PETROLEUM ACT CAP350. Accessed February 4, 2019.

32. Land Use Act, Chapter 202, Laws of the Federation of Nigeria, 1990.

33. The Constitution of the Federal Republic of Nigeria, 1999 (As Ameded). Section 44(3)

34. David Dafinone, "Resource control: the economic and political dimensions". Urhobo Historical Society. Ww.waado.org. Accessed on March 4, 2019

35. Okeke, "the Controversy over resource control”, In Okechukwu Okeke, et al (eds), Issues in Contemporary Nigerian History, 49.

36. See Nick Abonyi and Obikeze, O.S.A., "Revenue Allocation In Nigeria: A Historical Review", In Obi Emeka Anthony and Obikeze Sunday Obiajulu (eds), Federalism and National Integration In Nigeria. Onitsha: Abott Communications Ltd, 2004, 74-86.

37. Okeke, "The Controversy over resource control". In Okeke, et al (eds), Issues in Contemporary Nigerian History, 49

38. Clifford Ndujihe, "96 Trillion Oil Revenue: HowNigeria Short-changed Oil Producing Areas". Sunday Vanguard Newspaper, August 21, 2016.

39. See Peter P. Ekeh, “The mischief of history: Bala Usman's unmasking of Nigerian History”, The Guardian News paper, May 7, 2001, and G.G. Darah, "Bala Usman: History will absolve us". The Guardian Newspaper, May 14-16, 2001.

40. See Section 2 of the Nigerian Minerals and Mining Act,2007.

41. Okwudiba Nnoli, Ethnicity and Development in Nigeria. (London: Taylor and Francis Ltd,1995), 3.

42. Adeshina, "Revenue allocation commissions..., " In Restructuring In Nigeria, 242 